\title{
Intercultural Languages Education and Its Complex Insights: The Case of Indonesian Islamic Higher Education
}

\author{
Ribut Wahyudi \\ English Language and Letters Department, Faculty of Humanities and Culture, Maulana Malik Ibrahim State Islamic \\ University, Malang, Indonesia \\ Email: rwah5054@uni.sydney.edu.au
}

\begin{abstract}
The integration of intercultural aspects in teaching and learning on target language is salient as it would benefit both for communicative competence and minimizing the possible misunderstanding between second language learners and the speakers of the target language. The inter-cultural aspects themselves are regarded as the democratic view of learning the language as they look closely and compare the learner's culture and the target's language culture, similar to the concept of ethnographic conversations to enhance inter-cultural learning (Heuser, 2012). The elaboration of the concepts of language, culture and inter-culture as well as teacher's intra-cultural profile in relation to classroom pedagogy is essential. This would provide insightful knowledge for language teacher's professional development and second language learner for their learning process.
\end{abstract}

Index Terms -inter-cultural teaching, classroom pedagogy, intra-cultural profile, identity, intercultural stance and cultural knowings

\section{INTRODUCTION}

Every attempt to facilitate second language learners in a 'successful' communication in target language is deemed essential. The parameter of this success lies on at least two aspects; communicative aspect as well as intercultural aspect (Liddicoat \& Crozet, 2000, Liddicoat, 2004; Scarino, 2000; Sercu, 2002; Chavez, 2002). Furthermore, Corbett (2003, p.30) \& Alptekin (2002, p.57) summarise it as "intercultural communicative competence". This notion is logically understandable as language learners might create 'uninformed and unanalysed assumption derived from L1 culture' in which may result in misunderstanding while interacting with native speaker of the target language (Liddicoat, 2004; p.18). Moreover, 'intercultural communicative competence' itself may be the most appropriate goal with regard to the fact that 'language learning and teaching and culture are mutually implicated' (Atkinson, 1999, p. 647), as well as the concept that 'language expresses, embodies, and symbolizes cultural reality' (Kramsh, 1998a, cited in Risager, 2006, p.14). Thus, as the synergy of language and culture, intercultural communicative competence is required to avoid the potential problems (Liddicoat, 2004), e.g. misunderstanding of concept 'did you have a good weekend?' It is understood differently by French workers and local Australians, where French workers perceive it as a 'real question' requiring detailed answer but Australians consider it as a usual greeting which merely needs a short answer (Beal, 1992). In relation to this, McConachy (2008) explains that 'for second language learners understanding cultural significance of even relatively mundane conversational routines can prove to be problematic' (p.43).

As argued as the most appropriate answer to globalisation by Gundara \& Potera (2008), intercultural language education is projected to 'understanding and valuing all languages and cultures, one's own language(s) and culture(s), target language(s) and culture(s), how to mediate among languages and cultures as well as developing intercultural sensitivity (Commonwealth of Australia, 2004).

Realising the significant importance of intercultural language education and its possible contribution in language learning and teaching, this article will firstly, 'compare and contrast various scholars' definitions of language, culture and 'intercultural' along with its related terms such as cultural knowings, identity, language and classroom pedagogy, ethic and emic perspective, the potential challenges of intercultural teaching and secondly, describe my intracultural profile as well as its link to intercultural teaching practice as an on going professional development. My intercultural teaching is also provided at the end of article.

\section{The Definitions of LANGUAge, Culture AND InTERCUlture}

\section{A. Language}

There is no single definition about language. Different scholars have their own interpretations about language related to their area of expertise. The following are the examples of them. Language is defined as 'any basis of communication and understanding' (Macquarie dictionary, 2005, p.803). The example of this is language of flower, the language of 
laughter etc. Language 'also means many things, a system of communication, a medium for thought, a vehicle for literary expression, a social institution, a matter for political controversy, a catalyst for nation building'(O'Grady, Dobrovolsky, \& Katamba, 1996, p.1). A part from that 'language is not only the principle medium that human beings use to communicate with each other but also the bond that links people together and binds them to their culture. 'To understand our humanity we must understand the language that makes us human' (Bolton, 1994, p.1). Further, language 'serves to reinforce cultural identity' (Fowler, 1974, p.16). From several definitions above, despite the diverse interpretations, language shares the same function which is the means of social interaction.

\section{B. The Definition of Culture}

There is no consensus about the definition of culture. It thus has myriads of interpretations. Moran (2001) said that it is 'dynamic construction between and among people' lying 'at the crossroads of a number of fields of study and academic disciplines (anthropology, sociology, sociolinguistics, communication theory, intercultural communication, multicultural education, critical pedagogy, cultural studies, ethnic studies, history and semiotics' (p.4-5).

\section{Other five definitions of culture}

Some scholars view the culture as the static form and the other see culture as dynamic aspect (Commonwealth of Australia, 2004). In a static perspective, culture is seen as fact and artefact, while in a dynamic point of view, it seen as practices, beliefs and attitudes (p.8-9).

Kramsch (2006) divide culture from two perspectives: modernist perspective and post-modernist perspective. Modernist perspective, according to her, comprises of a 'humanistic concept', 'sociolinguistic concept', and 'intercultural language education'. On the other hand, post modernist perspective articulates culture as 'identity', as ''moral right to be heard and listened' (p.323-326). The above category might indicate that modernist perspective seems to deal with more practical concept 'interaction' while the latter one more on 'abstract' or 'philosophical level'.

Drawing from intercultural perspective, Scollon \& Scollon (2001) mention that culture is categorised into two; high culture and anthropological culture. Accordingly, high culture focuses on 'intellectual and artistic achievements' (p.139) e.g. art exhibits, concert performances, public lecturers while anthropological culture refers to 'any of the customs, worldview, language, kinship system, social organization, and other taken for granted day to day practices of people which set that group apart as a distinctive group'(p.139). Further, it is explained that it deals with 'any aspect of ideas, communications, or behaviour of a group of people which give to them a distinctive identity and which is used to organise their internal sense of cohesion and membership' (p.140). This latter definition would characterise more a particular community and distinguish them for other community which can be observed through daily interaction (Paltridge, 2006) in which intercultural notion seems to fit in.

Another interesting view of culture is in terms of its visibility, invisibility and multiplicity. (Bianco, 2003). Visible culture whether it is individual or collective are something that is observable, e.g. behaviour, decisions, behaviour patterns, rules, procedures, policy etc. Whereas invisible culture are those non-observable ones such as intentions, emotions, values, shared values, shared beliefs, assumptions etc. This concept is similar to the notion of culture as iceberg (Levine et al., 1987; Weaver, 1993; Brake et al., 1995 cited in Moran, 2001), in which 'explicit culture represents the tip of iceberg and the tacit culture is all that lies beneath the surface of the sea, out of sight' (p.27). Accordingly, the observable dimensions of culture are persons, communities, products and practices, where as tacit culture is associated with another dimension of culture, perspective.

\section{The relation between language and culture}

Language and culture are integral part and inseparable. The discussion of each of them connects to the other. Thus, it is said that 'language use is central to the construction and enactment of culture', 'culture cannot be learnt independently of language nor can language be learnt independently from culture', 'culture is learnt through language and language use' (Commonwealth of Australia, 2004, p.8).

Another importance view of language and culture is that language is 'linguistically formed culture and culture is non linguistically formed language' (Risager, 2006, p.6). This definition operates within specific level, differential sense as opposed to generic sense (language and culture are interwoven).

The next significant view of language in relation to culture is proposed by Fisman. Fishman (1985, 1991 and 1996 cited in Risager 2006) distinguishes three links between language and culture; 'language as a part of culture, language as an index of culture, and language as symbolic of culture' (p.13).

In summary, looking at overarching relation between language and culture and the definitions of culture itself, it might be beneficial to underline that every instance of language is a 'cultural act' (Kramsch, 1993) and that 'culture is not random, or idiosyncratic or wholly personal, but it refers to behaviour 'that is patterned, learned and social, but also changing and constructed' (Bianco, 2003, p. 25). In other words, human learn language and culture through their reciprocal and implicational relationship.

\section{Intercultural View}

The notion of interculture has gained growing popularity in language education. Byram (2001, cited in Harbon 2006) says that Intercultural Languages Education which 'underpins the school curriculum is in an increasing number of countries in the world' (p.28). This is as a response that over several decades up until 1990s, the teaching of language is separated from culture (Kramsch, 1993). Advocating the integration between language and culture, intercultural 
language teaching discusses plethora of issues such as languages education, cultural learning, teacher's talk and classroom interaction, cultural knowings, identity, intercultural stance, intercultural literacy, multicultural, emic and ethic perspective (Moran, 2001; Harbon; 2010, p.3-4).

As globalisation is argued as the real purpose of language teaching (Block, 2004), intercultural languages education is in response for this by; understanding and valuing all languages and cultures, one's target language and cultures, how to mediate among languages and cultures and developing intercultural sensitivity as an ongoing goal (Liddicoat, Papademetre, Scarino \& Kohler, 2003, cited in Harbon 2010, p.1). Therefore, with regards to these goals, the expected outcome are interculturally competent language users in the sense that they can interact effectively with people from a different culture, as well as being able to negotiate between his/her own and the target culture (Harbon, 2010).

As parts of intercultural view, the following related terms namely; cultural knowings, identity, language and classroom pedagogy, emic and ethics perspective are discussed.

\section{Cultural knowings}

As a means of describing culture, Moran (2001) introduces the terms cultural knowing, which is a framework for students to learn a target language. This concept comprises of knowing about, knowing how, knowing why and knowing oneself. Knowing about is the activities of gathering and demonstrating acquisition of cultural information such as facts, data, knowledge about products, practices and perspective about culture. Knowing how is the process of acquiring cultural practices which involves behaviour, actions, skills, saying, touching and others. The next stage is developing and understanding fundamental cultural views such as perceptions, beliefs, values, and attitudes underlying cultural practices. This stage is recognised as knowing why. As dealing with language learners stance in judging the target culture, knowing oneself, pertains to their opinions, feelings, questions, reactions, thoughts, ideas and own cultural values which is the central part of the cultural experience.

These aspects of knowings are very salient in the classroom in which teachers can teach interculturally. e.g. teacher's use of wedding invitation text (Johns, 1997) in order to facilitate student's intercultural awareness. This can be done by highlighting the 'value laden words' in the text, explaining the concept behind that value etc. Moreover, knowing the generic structure of wedding invitation in different countries as well as the content would be beneficial for students (Johns, 1997). Another example of this is given by Moloney and Harbon (2008), which suggests that student's intercultural ability success is 'firstly, to reflect and compare languages and cultures and secondly, to negotiate an individual and personal identity, constructed by their experience of spoken discourse' (p.111)

\section{Identity, language and classroom pedagogy}

As other concept of teaching and learning, it is obvious that intercultural language education is implemented in the classroom pedagogy. In its aim to integrate culture, the concept of identity is discussed as one of the central issues in it. Identity is ' who you are' (Joseph, 2006, p.486, Bloomaert, 2005, p.203). Moreover, Moran (2001) said that identity is 'both explicit and tacit that deal with our sense of self, values, beliefs and practices' (p.99), as identity is associated with the membership of other group, therefore aside from self-identity, there are group identities, national identities, gender identities, religious identities, social class identities etc (Joseph, 2006; Jones, 2000; Block, 2006). These identities are to some extent observable through the use of language. Le Page \& Tabouret-Keller (1985, cited in Risager, 2006), said that 'linguistic practice is acts of identity that allows us to operate in a whole range of different situations' (p.74). This operation might instigate diverse linguistic practices as people might become in more than one discourse community (Johns, 1997; Swales \& Feak, 2000; Paltridge, 2006). For instance, the same person may socially function as more than one role, as a mother, wife, lecturer etc. Looking at this practice of 'identity operation', therefore, Norton (2006) said that identity has opened up new research directions such as identity and investment in the target language, identity and imagined communities (learner's exposure in the target language), identity categories (sex, gender, race) and educational changes, identity and literacy (learner's ability to read and write).

In foreign language context, one identity may in some extent different when language learner uses his/her own language. Risager (2006) says that 'to participate in linguistic practice, a foreign-language speaker normally involves completely different identity dimensions from when one is speaking one's first language' (p.124) which is called third place identity (Kramsch, 1993), the state where one is in between his own language and target language. In intercultural language classroom, this issue may be addressed appropriately by giving questionnaire on 'intercultural sensitivity'. It is an advantage in that teachers can spot where students can put their identity in. This result may implicate to the choice of materials presented for classroom teaching (Bernett \& Allen, 2003).

Moran (2001) outlines four stages of intercultural learning in which students can learn in the classroom. These are; concrete experience, reflective observation, abstract conceptualisation, active experimentation (p.18). Similar to these notions, Commonwealth of Australia (2004) sets five principle of intercultural pedagogy; active construction; making connections; social interaction, reflection and responsibility. These aspects explore pedagogical notions in which students and teachers are 'engaged in creative process of learning' (Crozet \& Liddicoat, 1999, p.123, Phillips, 2001, p.4). For example teachers relate the concept of wedding in students' culture with that of in target culture. For further understanding students may interact with the native speakers of target language.

\section{Emic and ethic perspective}

As intercultural language education explores a target language as well as one's own language, language learners encounter reciprocal view of cultures. In one time, they have to see cultures from inside (emic) and on the other, they 
have to see their cultural practices from outside (ethics) Moran, (2001) states that emic perspectives "are those articulated by members of the culture to explain themselves and their culture", while ethic perspectives "are those of outsiders to the culture who use their own criteria to explain other cultures" (p.80).

The examples of ethic perspective are those given by anthropologists, cross cultural researchers. The categories upon certain culture cover family, kinship, individualism/collectivism, low-context, and high-context etc. In these examples, as outsiders, cultural researchers and anthropologists create their own terminologies and classifications about the culture that they are investigating. Therefore, it is common that there are different classifications and terminologies used by those scholars, in which this might be triggered by their idiosyncratic experiences during investigation.

Unlike, ethic perspective, emic perspectives may not correspond to ethic categories and may not have explicit terminologies. The insiders may find them easy to explain the cultural practices or find difficulty in expressing the culture verbally but they can figure out by giving real examples (Moran, 2001). In Indonesian example, it is not easy to explain the concept of Dewi Sri, as this deals with the myth and seems to be illogical for outsiders. In uncovering further about emic perspectives, language learners are encouraged to do ethnographic interview (Knutson, 2006; Cunico, 2005; Roberts et al, 2001 in Byram and Feng, 2006). The interview is conducted in the society of target language culture, so that they can get deeper understanding of cultural practices from the insider perspective. Another significance of having this ethnographic interview, aside from having deeper understanding, language learners can continually practice 'investigative skills' in order to negotiate and construe 'authentic meaning' of particular repertoires.

\section{The potential challenges of intercultural teaching}

No matter best the concept, there is always a potential drawback, as no single teaching approach is perfect (Lightbown and Spada, 2006). Therefore, there are caveats which need to be considered carefully. Crozet \& Liddicoat (1999, p.120-123) mention five areas in which Intercultural language teaching should address.

The first thing is that culture is not acquired through osmosis but it must be taught explicitly. The challenge for teachers is in this context is to identify 'cultural factor' either in spoken and written text prior to their teaching. In the process of cultural identification, however, it is teacher's challenge; for example, finding 'cultural value laden' words in the target language which is not always easy. As in the case for Australian teacher to teach Bahasa Indonesia by explaining Dewi Sri concept in Indonesian traditional farmers due to their different cultural background might be a challenging task. Moreover, it is said that teaching 'cultural factor' in the target language becomes more complex when teachers have to deal with multicultural background of students as they have to accommodate them interculturally for classroom activities. For example, teachers in Australia may encounter difficulties while teaching Japanese in the class where the students might be from Anglo Saxon background mixed with Arabic background. Thus mutual explorative process between teachers and learners is essential in doing classroom activities.

The second principle is that bilingual/ multilingual speaker is the norm. The crucial issue in this principle is that teachers should bear in mind that the goal of Intercultural Language Teaching (ILT) is the bilingual or multilingual speaker as opposed to 'native speaker'. Therefore the endeavour to facilitate them to have a multicultural view of world is prominent. In this context, teachers are challenged to create conducive environment for students to develop their bilingual/multilingual competence along with bilingual/multicultural world view.

The third principle is the idea that conceptual and experiential learning is required to acquire intercultural competence. In this concept, the big task for teacher is to introduce a new concept about languages and cultures. In achieving this, metalanguage such as genres, sociolinguistic norms, pragmatic norms etc should be taught. These complex areas require teachers to be well informed in multiple expertise. Further, providing adequate tasks in order for learners to creatively learn target language which accommodate cognitive and self-reflective development to negotiate 'meaningful resolution between the potential lingua cultural clashes' (p.122) is necessary. One of the examples of this is the sensitive issues regarding religion, which could be problematic among students in the classroom (Moran, 2001)

The fourth notion in ILT is the redefinition teacher's and learner's role. Well informed teacher functioning as colearner of language as well as co-learner of culture is salient in this concept. This also advocates that the class should focus on learner-centred in which they are taught 'cultural factor' in the target language in a democratic way. Moreover, teacher's well-informedness on this role should be confirmed in the first place before they teach interculture. However, it might be a challenging task for teachers for example in Asian contexts in which teachers mostly perform in a bit more authoritative ways (Ballard \& Clancy, 1997).

The last principle to consider in ILT is the need to have new approaches to assess intercultural competence. Yet, measuring the cultural content embedded in curriculum documents and assessment scales which cater 'more holistic and the dynamic view of language education' (Crozet \& Liddicoat, 1999, p.122) which focus on 'process and product' is in need of attention. Underlining this notion (Schulz, 2007, p.9) said that how 'culture should be defined operationally in the context of foreign language curriculum' and how the assessment of culture is done is somewhat problematic. In order to do this, (Lussier, et al., 2007) propose three steps in assessing students' performance and perceptions. This include when to assess, what to access and how to access. Time to assess covers before teaching interculture, during and after teaching that unit. The aspects to be assessed are knowledge (savoir), knowing how (savoir-faire), being (savoir etre). While the way to assess include self-evaluation, culture log, port-folio, self-evaluation, and other tasks which require the students to compare, explain, synthesize, discuss, debate, role-play, write an essay, justify their opinions etc. 
In Indonesian educational settings, intercultural aspect has not gained considerable attention. It can be seen that most in English texts in secondary levels, the cultural aspect given is in inadequate amount. Moreover, it is perhaps merely in the form of cultural notes. In tertiary level, especially in English department, cross-cultural understanding is given mostly as an elective unit. In her conclusion of dissertation Wangsalegawa (2009) said that 'even though Indonesia must keep up with globalisation, it does not have to surrender its own cultural values. Indonesians from various professions question the lack of cultural values in the current education system' (p.158).

Looking at these facts, there are several challenges for the integration of intercultural language education in Indonesia. First of all, there should be a political will in Indonesian curriculum to integrate more about intercultural aspect to national curriculum in all educational level. Secondly, it should be noticed that 'intercultural aspect' could be operationally implemented in accordance with multiculturalism in each areas, as multicultarism in Java may be dissimilar to that of Bali, Sumatera etc. On the other hand, in tertiary level, intercultural language education should be given as a compulsory subject for teacher training students, as Jokikokko (2005) mentions that 'as schools become increasingly multicultural, teachers need special sensitivity to recognise differences and intercultural differences to be able to support personal and academic growth of diverse students'(p.69).

What is being faced in the Indonesian curriculum seems to be parallel with intercultural language teaching in China, the problems of which are: the lack in cross-cultural oriented curriculum, the conventional roles of EFL teachers and learners, and the lack of intercultural oriented course book (Ge \& Zhen, n.d). This similarity might be caused by similarity of the educational cultural background in both countries (Ballard \& Clancy, 1997).

\section{My INTRACULTURAL PROFILE}

Name: Ribut Wahyudi

Place of birth: Jember, Jawa Timur

Place of upbringing: Jember, Jawa Timur

Places of Education: Jember, Denpasar (Indonesia), Sydney

Primary: SDN Sanenrejo VII (Elementary School), Tempurejo, Jember

Secondary: SMPN 2 Tempurejo (Junior High School), SMUN 3 Jember (Senior High School)

Tertiary: The University of Jember, Indonesia Australia Language Foundation (IALF) Denpasar, the University of Sydney.

Languages (variations) I use for daily communication/interaction (listening \& speaking):

Indonesian, Javanese

Languages (or variations) I use for daily communication/interaction (reading \& writing)

Indonesian

Languages (or variations) I use for teaching:

Listening and speaking: English \& Indonesian

Reading and Writing: English

Other languages (or variations) I use in my study \& research:

Other languages (or variations) I have used in the past in my studies \& research, or for communication and interaction (where \&when):

What is my relationship to:

English and its varieties: foreign language

The target language I teach and its varieties:

Australian culture: the third space

Additional languages/cultures: French (two semester course) and Japanese (one-semester course).

Tertiary subjects I have studied (and am studying) relevant to my practice; (place \& institution): Discourse analysis, Psycholinguistics, writing, speaking, Sociolinguistics, the University of Jember.

\section{Employment:}

Present (area(s), subject(s) \& where: the State Islamic University of Malang, English for Specific Purposes and debating skills, East Java, Indonesia

Past (area(s), subject(s) \& where: DELTA (Private Course for student's university entrance exam preparation), the State College of Islamic Studies, English for exams and English for Specific Purposes, Jember, East Java, Indonesia.

\section{Fundamental domains:}

Base culture and language: Javanese Indonesian

Occupation/profession/practice: university lecturer

Other engagement/involvement: debate trainer, the secretary of International Student's Affairs unit.

\section{Intracultural based teaching}

In delivering his/her teaching, teachers are inevitably influenced by his/her own experience in learning first language. It is stated that "a teacher's own values and beliefs, experiences and practices can not be divorced from the act of teaching and learning" (Professional Standard Project, 2008). This intracultural experience requires teachers to be aware of his/her position relationship, the source of understanding, the provider of the understanding, the similarity and differences of those understanding in both one's culture and target culture, how teachers make use of those 
understanding to enhance teaching (Harbon, 2010). Papadametre (2005) encourages 'self-reflection to channel intracultural with intercultural knowing' for teachers (p.8), on the basis of self reflection on ideology, ideological engagement with intercultural education, operationalisation of intercultural learning to develop intercultural curriculum through reciprocal relationship. It is worthy of note that teacher is driven by beliefs, values while teaching in the classroom (Dogancay-Aktuna, 2005; Papadametre, 2005).

The following are my sociocultural and linguistic identity in terms of three domains; base culture and language, occupation/profession/practice and other engagement/involvement.

\section{Base culture and language}

I am the fifth child as well as the last son in Javanese family, born and raised in Jember, East Java. Quite different from central Java which is mostly from Javanese tribe, East Java, Indonesia, is quite mixed with Madurese. Although, Javanese tribes still hold the majority in this province. So our Javanese family in some way is quite dissimilar to those Javanese in Central Java. My family is culturally shaped by Islamic values. In other words, my upbringing lies on two pillars, Javanese and Islamic values. Not very much strict like in Central Java, Yogyakarta, Solo, in which three speech level and pitch, intonation are exercised carefully, I use ordinary Javanese language in my family. This might be the result that my father and mother did not necessitate me to use 'krama inggil', the highest speech level in Javanese language. I use 'krama inggil', only to older people outside my family, and yet it is also not very intensive.

As for bahasa Indonesia, I started to learn it in primary school onwards, in which it is the compulsory medium of instruction. Slightly different from Javanese language which has different speech level, Bahasa Indonesia seems to be more democratic and egalitarian. For example: there is only one 'you' which is 'kamu' while in Javanese, there is 'panjenengan', which is the most polite form of 'you', 'sampeyan' which is less polite, and 'kowe' which is the ordinary one. However, it is not advisable to use 'kamu' to the one being respected, rather it is usually 'Bapak X', 'Ibu $\mathrm{Y}^{\prime}$ etc. I include this aspect in my teaching as well.

\section{English learning experience}

I started learning English in Junior high school, where English was a compulsory subject as also in the case of Senior high school. It is important to note when I was in junior high school that I was urged by my brother by saying that "if your English is not good, if you wish to continuing studying in the city, you will be left behind". This statement is very powerful and influential in motivating me in learning English. Being raised in the village, I am motivated a lot to learn English. This was in part due the societal view in my village that English is a prestigious language. Thus, mastering it indicates 'self-pride'.

Looking through the contexts of learning, in Junior and Senior High School, my learning was primary accentuated on form, reading, grammar, rather than productive skills such as writing and speaking. The activities done in the classroom were also very much guided by a compulsory book produced by the government and taught by local teacher.

However, the context altered when I enrolled in the university, in which I was doing English as my major. In this stage I began to develop four integrated skills: reading, writing, speaking and listening in much more compatible ways. Furthermore, I was taught by many of lecturers from overseas graduates. The experience of doing either master or PhD abroad was indeed contributed much on the way they provided more insightful and plausible explanations. Another conducive atmosphere was when I was joining six month English for Academic Program (EAP) at Indonesia Australia Language Foundation (IALF) Bali. In this foundation I was taught academic English and cross cultural understanding by native speakers. Furthermore, adequate learning resources such as multi-media, regular-monitoring progress are of the advantage.

Moreover, the opportunity to have a contact with Canadian, Australian, German friends boosted my confidence to use more spoken English. The exposure on spoken English was even much facilitated when entering university. In the university, I became an active organiser of two English clubs. My positions in these organisations benefited me a lot, in which I could run discussions, act as radio announcer, represent in English debate competitions etc. These provided me rich experience to learn English from outside the classroom settings, a side from those of formal classes.

Summarising the above experience, the key factors facilitating my learning success are positive rapport with teachers and lecturers, involvement in English competitions, being the organisers of English clubs, contact with native speakers and so on. It is inevitable indeed that our relationship with teachers or lecturers might probably affect the way we view subjects they teach. Closed relation that I usually have with teachers would drive me to love the subjects they teach. Moreover, this benefited me a lot in that I could ask for a help to them every time I had a problem. Immersing me to English clubs was quite helpful for me to keep on using English, at least more frequently than those who were not involved into them. Even more advantage, I could broaden the knowledge not only in the area of English but general knowledge as well because the members were from diverse faculties. Outside the formal classroom, I could interact with native speakers even though it was not in regular interval. The opportunity to socially interact with native speakers opened widely while I was doing English for Academic Program (EAP) at IALF Bali. Being taught by native speakers I could learn more about pronunciation, the appropriate use of words and more importantly cultural understanding as well, as one of the courses given was cross-cultural understanding.

\section{The domain my occupation/profession/practice}

I started teaching secondary students in DELTA, a private course institution in Jember, East Java, in August 2004, when I was about to finish my undergraduate degree. DELTA provides a range of different disciplinary courses in 
which English is one of them. The main purpose of this course is to prepare students for the exams, primarily national exam and university entrance exams. In line with the purpose of this course, the English materials given is much of exam oriented, in which students are prepared to do multiple choice test. Additionally, this course is more on grammar, reading less on listening. So no intercultural space is given in this course.

In recruiting the teachers, this private institution does not require the teachers to have teaching qualification, which allowed me from English literature and linguistic background to join. The recruitment process was based on doing multiple choice tests and teaching performance. The institution applied a quite democratic approach of teaching in that students are given room to evaluate teacher's teaching performance in the classroom. Moreover, they can reject a certain teacher if the teachers are felt less competent both in terms of subject mastery or teaching performance. In this context, I was learning a lot how to intellectually engage with English material for exam as well as to emotionally engage with students. And yet, this led me to believe that the success of teaching should perform two sides; subject mastery and teacher-students' emotional engagement.

My other teaching career was at the State College of Islamic Studies (STAIN Jember). In this college I was teaching English for specific purposes, teaching basic English for students doing Arabic studies. The focus of this was very much on reading materials followed with question on Islamic topics. In this case, English is simply utilised as a medium of instruction and only Islamic based cultural value presented. Synergizing this with the objective of the teaching, the activities were very much on reading comprehension, grammar, and listening.

After one semester teaching at STAIN Jember, I moved to teach at the State Islamic University of Malang. At this university, I was teaching English for specific purposes for Islamic education students. The goal for this teaching was reading comprehension on Islamic topics. Besides that I trained a debate in student's debate community.

Other involvement or engagements

Additional affiliations: spiritual community, university student English forum, English department student association

Leisure hobbies: listening music

Food: slow and fast food

\section{A. The Link of My Intracultural Profile with My Previous Teaching Practice as an Ongoing Professional Development}

I always try to incorporate my experience which is relevant to teaching activities. While I was teaching at DELTA, I try to incorporate personal experience communicating with native speakers whenever the topic of multiple choices does relate to, but since the nature of the course is only exam oriented, it did not provide intercultural aspect. While teaching English for Specific Purposes (ESP) both at the State College of Islamic Studies (STAIN Jember) and the State Islamic University of Malang (now Maulana Malik Ibrahim State Islamic University), again the culture aspects were less presented as the topic itself focus more on 'guided' topics or issues. However, as while teaching I often encouraged the students to have a direct communication with native speakers in order to improve their English as well as to know more about the native speaker's cultures. While training debate, however, I had more chance to share my personal experience to students as well as motivate them to gain academic success especially in English Language. Moreover, for students who keep contact with me and wish me to proof read their scholarship application, I suggested them the way in which the writing style of Anglo Saxon is done, so that the application could follow the same pattern as scholarship committee would expect.

\section{B. My Intercultural Teaching}

I am teaching for English department students for bachelor level for several courses; Speaking, Writing, Introduction to Linguistics, Syntax, and Structure. I include intercultural aspect in my teaching. For example trying to incorporate to some extent knowing about, knowing how, knowing why, knowing one-self. These can be exercised in the form of writing, reading, speaking, pragmatic etc. as cultural transmission can be pervasive in all aspect of language learning. As these students I assume are mostly in the late intermediate or advanced learners, they are more probably at different seekers stage (Bernett \& Allen 2003). Therefore, teaching interculture through literary works such as drama could be interesting (Cunico, 2005) as besides knowing the culture, they can perform a role play. This can be fruitful to implement 'intercultural communicative competence' in the sense that speaking is also exercised. Moreover, as I train and advise 'debate' in the university, providing current and contested topics for global issues is of considerable important. Sharing my own intra-cultural experience during study in Australia would likely be insightful. In terms of 'communicative competence', I let them know about the path of my learning experience as well.

However, I am cautious to the fact that 'religious issues', as described in (Moran, 2001) can be very sensitive. This should be better implemented in each disciplinary course or curriculum, as Slaterry (2006) describes that 'religion, spirituality and culture and the ways that these important dimensions of human life and society inform and are informed by curriculum studies', (p.71). Considering that I am teaching in 'religious based university' where students may have different interpretations about certain religious issues. In order to do it better, I try to raise the awareness of appreciating and respecting other cultures by connecting some of the teaching in holy book (Al-Quran) that suggests this such as the idea that human being is created in different nations, tribes in order to know each other. This could be the starting point of discussion in the classroom where the language educator could introduce the idea of respecting others. In the language learning process, however, I leave the students to decide their intercultural stance (third place) on their own. 
But one important thing is that encouraging them to have 'investigative framework' in their language learning (Borg, 1994), so that they would be well informed in deciding the stance of positioning one-self among different cultures by upholding their own and respecting others.

\section{ACKNOWLEDGEMENT}

I would like to thank to Associate Professor Lesley Harbon, at Faculty of Education and Social Work, the University of Sydney. She was teaching me a course on Intercultural Languages Education. This article was one of the assignments in the course. Without her evaluative assessment, this article could not have been better.

\section{REFERENCES}

[1] Alptekin, C. (2002). Towards intercultural communicative competence in ELT. ELT Journal. 56(1), 57-64.

[2] Atkinson, D. (1999). TESOL and culture. TESOL Quarterly. 33(4), 625-654.

[3] Ballard, B. \& Clancy, J. (1997). Teaching international Students: A brief guide for lecturers and supervisor. Deakin A.C.T.: IDP Education Australia.

[4] Beal, C. (1992). Did you have a good weekend? Or why there is no such thing as a simple question in cross cultural encounters. Australian Review of Applied Linguistics. 15(1), 23-52.

[5] Bernett, M. J. \& Allen, W. (2003). Developing intercultural competence in the language classroom. In D. L. Lange \& R. M. Paige. Culture as the core: Perspective on culture in second language learning (p.237-270). Greenwich, Conn: Information Age Pub.

[6] Block, D. (2004). Globalisation and language teaching. ELT Journal. 58(1), 75-77.

[7] Block, D. (2006). Identity in applied linguistics. In T. Omoniyi and G. White (Eds). The Sociolinguistic of Identity. London: Continuum.

[8] Bloomaert, J. (2005). Discourse analysis. Cambridge: Cambridge University Press.

[9] Bolton, W. F. (1994). Language: An introduction. In V.P. Clark, P.A. Eschholz \& A. F. Rosa. (Eds). Language: Introductory reading (p.1-16). New York: Saint Martin Press.

[10] Borg, S. (1994). Language awareness as a methodology: implications for teachers and teacher training. Language Awareness. 3(2), 61-71.

[11] Byram, M \& Feng, A. (2001). Culture and learning: teaching, research and scholarship. Language Teaching. 37, $149-168$.

[12] Chaves, M. (2002). We say “culture' and students ask "what"?: University definitions' definitions of foreign language culture. Teaching German. 35(2), 129-140.

[13] Commonwealth of Australia (2004). Getting started with Intercultural Language Learning: A resource for schools. The Asian Languages Professional Learning Project.

[14] Corbett, J. (2003). An Intercultural approach to second language education. In J. Corbet. An Intercultural approach to English Language Teaching (p.1-30). Clevedon: Multilingual Matters.

[15] Crozet, C. \& Liddicoat, A. (1999). The Challenge of intercultural language teaching: Engaging with culture in the classroom. In J. Lo Bianco, Liddicoat, A., Crozet, C. (Eds). Striving for the third place-intercultural competence through language education (p.113-125) Melbourne: Language Australia.

[16] Crozet, C. \& Liddicoat, A. (2000). Teaching culture as an integrated part of language: Implications for aims, approaches, and pedagogies for language teaching. In A. J. Liddicoat \& C. Crozet (Eds). Teaching language, Teaching culture. (p. 1-18). Melbourne: Applied Linguistics Association of Australia and Language Australia.

[17] Cunico, S. (2005). Teaching languages and intercultural competence through drama: some suggestions for a neglected resource. Language Learning Journal. 31(1), 21-29.

[18] Dogancay-Aktuna, S. (2005). Intercultural communication in English language teacher education. ELT Journal. 59(2), 99-107.

[19] Fowler, R. (1974). Understanding language: An introduction to Linguistic. London: Routledge \& Kegan Paul.

[20] Ge, W. \& Zhen, Z. (n.d.) Intercultural language teaching in China: Problems and prospects. Paper presented at the $2^{\text {nd }}$ International Conference on Foreign Language Teaching Methodology. Hong Kong: Authors.

[21] Gundara, J. S. \& Potera, A. (2008). Theoretical reflections on intercultural education. Intercultural Education. 19(6), 463-468.

[22] Harbon, L. (2006). Intercultural languages education. Babel. 41(1). 28-38.

[23] Harbon, L. (2010). Intercultural Languages Education: lecture note week 1, week 3 \& week 12. Faculty of Education and Social Work. The University of Sydney.

[24] Heuser, L. (2012). Ethnographic conversations: A pedagogical strategy to promote language, content, and intercultural learning among Japanese and American University students. Asian EFL Journal, 57, 4-23.

[25] Johns, A. M. (1997). Text, role, and context: Developing academic literacies. Cambridge: Cambridge University Press.

[26] Jokikokko, K. (2005). Interculturally trained Finnish teacher's conceptions of diversity and intercultural competence. Intercultural Education. 16(1), 69-83.

[27] Jones, B. (2000). Developing cultural awareness. In K. Field (Ed). Issues in modern foreign language teaching. London: Taylor \& Francis Group.

[28] Josef, J.E. (2006). Identity and language. In K. Brown (Ed). Encyclopedia of language and Linguistics (p.486-492). New York: Elsevier.

[29] Knutson, E. M. (2006). Cross cultural awareness for second/foreign language learners. The Canadian Modern Language Review. 62(4), 591-610.

[30] Kramsch, C. (1993). Context and culture in language teaching. Oxford: Oxford University Press.

[31] Kramsch, C. (2006). Culture in language teaching. In K. Brown, (Ed.). Encyclopedia of language and Linguistics (2 ${ }^{\text {nd }}$ Ed.). (pp. 322 - 329). London: Elsevier.

[32] Liddicoat, A. (2004). Intercultural language teaching: principles for practice. The New Zealand Language Teacher. 30 , 17-23. 
[33] Lightbown, P. M. \& Spada, N. (2006). How languages are learned. Oxford: Oxford University Press.

[34] Lo Bianco, J. (2003). Culture: Visible, invisible and multiple. In J. Lo Bianco \& C. Crozet, (Eds). Teaching invisible culture: Classroom practice and pheory (p.11-38). Melbourne: Language Australia.

[35] Lussier, D., et al., (2007). Guidelines for the assessment of intercultural communicative competence (ICC). In I. Lazar, M. Huber-Kriegler, D. Lussier, G. S. Matei \& C. Peck (Eds). Developing and assessing intercultural communicative competence: A guide for language teachers and teacher educators (p.23-35). European Centre for Modern Languages/Council Europe. Austria: Council of Europe Publishing.

[36] Macquarie Dictionary. (2005). Sydney: the Macquarie Library Ptd Ltd.

[37] McConachy, T. (2008). Teaching for intercultural awareness through a focus on conversational routines. The International Journal of Language Society and Culture. 24, 43-49.

[38] Moloney, R. \& Harbon, L. (2008). I speak therefore I am: Self-perceptions of identity in immersion language learners as an expression of intercultural competence. The University of Sydney Papers in TESOL, 3, (p.111-129).

[39] Moran, P. R. (2001). Teaching culture: Perspective in practice. Boston: Heinle \& Heinle

[40] Norton, B. (2006). Identity: second language. In K. Brown (Ed). Encyclopaedia of language and Linguistics (p.502-508). New York: Elsevier.

[41] O’Grady, W., Dobrovolsky, M., \& Katamba, F. (1996). Contemporary Linguistics: An introduction. London: Longman.

[42] Paltridge, B. (2006). Discourse analysis. London: Continuum

[43] Papadametre, L. (2005). Intra-cultural considerations for intercultural teacher education. Australian Language and Literacy Matters. 2(1), 5-10.

[44] Phillips, E. (2001). IC? I see!: Developing learner's intercultural competence. LOTE CED Communique, 3. Available online at: www.sedl.org.loteced. Accessed on May 20, 2010.

[45] Professional standards project (2008). Canberra: Commonwealth of Australia.

[46] Risager, K. (2006). Language and culture in a global perspective. In K. Risager. Language and culture: Global flows and local complexity (p.1-18). Clevedon: Multilingual Matters.

[47] Scarino, A. (2000). The neglected goals of language learning. Babel. 3, 4-11.

[48] Schulz, R. A. (2007). The challenge for assessing cultural understanding in the context of foreign language instruction. Foreign Language Annals. 40(1), 9-26.

[49] Sercu, L. (2002). Autonomous learning and the acquisition of intercultural communicative competence: Some implications for course development. Language, Culture and Curriculum. 15(1), 61-74.

[50] Slattery, P. (2006). Curriculum development in the post modern era. New York: Routledge.

[51] Swales, J. \& Feak, C. B. (2000). English in today's research world: A writing guide. Ann Arbor: The University of Michigan Press.

[52] Wangsalegawa, T. (2009). Origins of Indonesian curriculum theory and practice: Possibilities for the future: Dissertation at University of Illinois at Chicago.

Ribut Wahyudi hold an M.Ed degree in TESOL from The University of Sydney Australia in 2010. He has been teaching skill and content courses in Linguistics at Maulana Malik Ibrahim State Islamic University, Malang, Indonesia. He is interested in researching Intercultural Languages Education, DA, CDA, SLA and Curriculum and Pedagogy. He has published his articles in the following Journals: LiNGUA 2011, Research on Humanities and Social Sciences www.iiste.org 2012, Language, Discourse and Society 2012, and the State University of Malang Press 2012. Furthermore, he has presented his papers in national and international seminars. 